\title{
The Hopanoids of 'Methylosinus trichosporium': Aminobacteriohopanetriol and Aminobacteriohopanetetrol
}

\author{
By SERGE NEUNLIST AND MICHEL ROHMER* \\ Ecole Nationale Supérieure de Chimie de Mulhouse, Université de Haute Alsace, \\ 3 rue Alfred Werner, 68093 Mulhouse Cedex, France
}

(Received 16 October 1984 ; revised 10 January 1985)

Triterpenoids belonging to the hopane family are widespread among prokaryotes. The two major hopanoids isolated from the methylotrophic bacterium 'Methylosinus trichosporium' grown on methane or methanol were identified by spectroscopic methods as the aminotriol 35-aminobacteriohopane-32,33,34-triol and a novel aminotetrol, 35-aminobacteriohopane31,32,33,34-tetrol. The former hopanoid has been previously isolated from the purple nonsulphur bacterium Rhodomicrobium vannielii.

\section{INTRODUCTION}

The hopanoids are the most widely distributed triterpenoids among prokaryotes (Rohmer $e t$ al., 1979, 1984). The major compounds are always derived from a $\mathrm{C}_{35}$ bacteriohopane skeleton (Förster et al., 1973), which is composed of a $C_{30}$ pentacyclic triterpene, hopane, linked to a polyfunctionalized $\mathrm{C}_{5}$ normal acyl chain. By comparison with synthetic hopanoids, it has been shown that the normal acyl chain is linked to the C-30 carbon atom of the hopane side-chain (Rohmer \& Ourisson, 1976a). Most of the methylotrophic bacteria, growing on either methane or methanol, are good hopanoid producers. In a previous study (Rohmer et al., 1984), we have shown that the methylotroph 'Methylosinus trichosporium' grown on methane contains at least two bacteriohopane derivatives which release a $\mathrm{C}_{32}$ (III) and $\mathrm{C}_{31}$ (IV) primary alcohol on treatment by our standard periodic acid/sodium borohydride $\left(\mathrm{H}_{5} \mathrm{IO}_{6} / \mathrm{NaBH}_{4}\right)$ side-chain cleavage method (Fig. 1). The $\mathrm{C}_{32}$ alcohol could be derived from the bacteriohopanetetrol already isolated from Acetobacter aceti subsp. xylinum (Förster et al., 1973; Rohmer \& Ourisson, 1976a) or from Bacillus acidocaldarius (Langworthy \& Mayberry, 1976). The $C_{31}$ alcohol, however, could arise from a pentol or a pentol derivative which has already been isolated in small amounts from the cyanobacterium Nostoc muscorum (Rohmer, 1975; Rohmer \& Ourisson, $1976 b$ ), but not in sufficient amounts for a full characterization. This paper describes the isolation and the identification of the hopanoids of 'Methylosinus trichosporium': 35-aminobacteriohopane-32,33,34-triol (I) and 35-aminobacteriohopane-31,32,33,34-tetrol (II) (Fig. 1).

\section{METHODS}

Strain and cultiration. 'Methylosinus trichosporium' NCIB 11131 was obtained from the National Collection of Industrial Bacteria (Aberdeen, UK) [it was referred to as 'Methylosinus trichosporium' OB3b in our previous paper (Rohmer et al., 1984)]. The name is placed in quotation marks since it is not on the Approved Lists of Bacterial Names (Skerman et al., 1980) or subsequent validation lists published in the International Journal of Systematic Bacteriology'. Growth on methane was done as by Whittenbury et al. (1970), for $3 \mathrm{~d}$ in stoppered 2 litre Erlenmeyer flasks at $30^{\circ} \mathrm{C}$ on a rotatory shaker (yield about $240 \mathrm{mg}$ dry wt $\mathrm{l}^{-1}$ ). Cells were also adapted to methanol growth (Whittenbury et al., 1970; Hou et al., 1978); they were grown in the same conditions and on the same ammonium/mineral salts medium, but with methanol $(2 \%, \mathrm{v} / \mathrm{v})$ as carbon source instead of methane (yield about $300 \mathrm{mg}$ dry wt $\left.\mathrm{1}^{-1}\right)$. The cells were harvested by centrifugation $\left(10000 \mathrm{~g}, 10 \mathrm{~min}, 4^{\circ} \mathrm{C}\right)$ and freeze-dried.

Analytical methods. TLC was done on hand-made Merck $7747 \mathrm{~K}$ ieselgel 60PF 254 plates ( $1 \mathrm{~mm}$ thickness) or on Merck 5715 HF254 silica gel plates $(0.25 \mathrm{~mm})$. The lipids were visualized under $360 \mathrm{~nm}$ UV light after spraying 
with a $0.1 \%$ ethanolic solution of berberine chlorhydrate (Rohmer et al., 1984). The bands containing the hopanoids were scraped off and the triterpenoids recovered with chloroform/methanol $(2: 1, v / v)$. HPLC was done with a Waters $\mu$-Bondapak $C_{18}$ column $(300 \times 3.9 \mathrm{~mm})$, methanol/water $\left(93: 7, \mathrm{v} / \mathrm{v}, 2 \mathrm{ml} \mathrm{min}^{-1}\right)$ as solvent and a Waters R401 differential refractometer detector. GC was done with a glass capillary column (OV-1, 25 m) using an on-column injector; the oven temperature was programmed from $60^{\circ} \mathrm{C}$ to $220^{\circ} \mathrm{C}\left(30^{\circ} \mathrm{C} \mathrm{min}-1\right), 220^{\circ} \mathrm{C}$ to $280^{\circ} \mathrm{C}$ $\left(3{ }^{\circ} \mathrm{C} \mathrm{min}{ }^{-1}\right)$ and $280^{\circ} \mathrm{C}$ to $310^{\circ} \mathrm{C}\left(5^{\circ} \mathrm{C} \mathrm{min}^{-1}\right)$; the flame-ionization detector was at $310^{\circ} \mathrm{C}$. GC-MS was done at $70 \mathrm{eV}$ on an LK B $9000 \mathrm{~S}$ spectrometer fitted with a capillary SE-30 column as previously described (Rohmer et al., 1980). Direct inlet mass spectra were recorded at $70 \mathrm{eV}$ on a modified Thomson THN 208 spectrometer using a fast heating technique for less volatile compounds (Dessort et al., 1982). Nuclear magnetic resonance (NMR) spectra were recorded on a Varian T60 or a Bruker W200 instrument using $\mathrm{C}^{2} \mathrm{HCl}_{3}$ and $\mathrm{CHCl}_{3}(\delta=7 \cdot 265$ p.p.m.) as internal standard for ${ }^{1} \mathrm{H}-\mathrm{NMR}$ and $\mathrm{C}^{2} \mathrm{HCl}_{3}(\delta=77.0$ p.p.m. $)$ for ${ }^{13} \mathrm{C}-\mathrm{NMR}$.

Isolation of the hopanoids. The freeze-dried cells $(6 \mathrm{~g})$ were extracted three times under reflux for $1 \mathrm{~h}$ using chloroform/methanol $(100 \mathrm{ml}, 2: 1, \mathrm{v} / \mathrm{v})$. After filtration, the combined extracts were evaporated to dryness under vacuum and treated according to one of the following procedures. (1) The crude extract was treated first with a solution of $\mathrm{H}_{5} \mathrm{IO}_{6}$ and then with $\mathrm{NaBH}_{4}$ (Rohmer et al., 1984). The primary alcohols (III) and (IV) (Fig. 1) arising from the cleavage of the bacteriohopanepolyols were isolated by TLC and acetylated, and their acetates identified by GLC and GLC-MS (Rohmer et al., 1984). (2) The crude chloroform/methanol extract was acetylated overnight at room temperature with an excess of acetic anhydride/pyridine $(1: 1, \mathrm{v} / \mathrm{v})$. Excess reagent was removed under reduced pressure, and the residue separated by TLC using chloroform/methanol $(95: 5, \mathrm{v} / \mathrm{v})$ as eluent, giving peracetylated (I) $\left(R_{F}=0 \cdot 36\right)$ and peracetylated (II) $\left(R_{F}=0.32\right)$. These hopanoid polyacetates were further purified by reverse-phase HPLC.

Details of the mass and NMR spectra have been deposited with the British Library Lending Division, Boston Spa, Yorkshire LS23 7BQ, UK, as Supplementary Publication no. SUP 28018 (7 pages). Copies may be obtained from the BLLD on demand; wherever possible, requests should be accompanied by prepaid coupons held by many university libraries and the British Council. The material deposited comprises mass spectra of peracetylated (II), (III) and (IV), including chemical ionization data for the derivative of (II), ${ }^{1} \mathrm{H}-$ and ${ }^{13} \mathrm{C}-\mathrm{NMR}$ spectra of peracetylated (I), and the ${ }^{1} \mathrm{H}-\mathrm{NMR}$ spectrum of (II). Tentative assignment of the ${ }^{13} \mathrm{C}-\mathrm{NMR}$ signals was done by using a J-modulated spin echo technique and data obtained on tetra-acetoxybacteriohopane (J. M. Renoux \& $M$. Rohmer, unpublished results).

\section{RESULTS}

A preliminary $\mathrm{H}_{5} \mathrm{IO}_{6} / \mathrm{NaBH}_{4}$ treatment of a sample of the crude 'Methylosinus trichosporiurn' extract released only two primary alcohols (Fig. 1) having a $\mathrm{C}_{32}$ (III) or a $\mathrm{C}_{31}$ (IV) skeleton, in the ratio $70: 30$. This result shows that two bacteriohopanepolyols with two free hydroxyl groups either at C-32 and C-33 or at C-31 and C-32 were present. The acetate of III was identical (GC and GC-MS) to the derivative obtained from Acetobacter aceti subsp. xylinum and to synthetic material (Rohmer \& Ourisson, 1976a). Furthermore, the methyl region of the ${ }^{1} \mathrm{H}-\mathrm{NMR}$ spectrum of the peracetylated hopanoid (I) as well as its ${ }^{13} \mathrm{C}$-NMR spectrum showed clearly that this compound is a typical bacterial hopanoid with an assumed $22 R$ configuration (Rohmer \& Ourisson, $1976 a$; J. M. Renoux \& M. Rohmer, unpublished results).

The aminotriol (I) $\left[2.8 \mathrm{mg}\right.$ (g dry wt) $\left.{ }^{-1}\right]$ was identical (TLC behaviour, ${ }^{1} \mathrm{H}-\mathrm{NMR}$ ) to the aminotriol already isolated from the purple non-sulphur bacterium Rhodomicrobium vannielii (Neunlist et al., 1984, 1985). The amino group may be located at C-35; the signals of the two protons at $\mathrm{C}-35$ in peracetylated (I) were shifted upfield at 3.37 and 3.69 p.p.m., whereas they appeared at 4.14 and 4.39 p.p.m. in the spectrum of the tetra-acetoxybacteriohopane isolated from Bacillus acidocaldarius or from Methylobacterium organophilum (J. M. Renoux \& $\mathbf{M}$. Rohmer, unpublished results). Furthermore, the signal of the C-35 carbon atom was also shifted upfield : it appeared at $39 \cdot 2$ p.p.m. in the ${ }^{13} \mathrm{C}-\mathrm{NMR}$ spectrum of the acetylated hopanoid (I) and at 62.1 p.p.m. in the spectrum of tetra-acetoxybacteriohopane (J. M. Renoux \& M. Rohmer, unpublished results).

Compound (II) differs from the aminotriol (I) by the presence of an additional hydroxyl group. This was already suggested by the direct inlet mass spectrum of the penta-acetate of (II), which showed a molecular ion at $m / z 771$ and a ring $C$ (Fig. 1) cleavage fragment (Budzikiewicz et al., 1963) at $m / z 550$. This molecular weight of 771 was confirmed by chemical ionization mass spectrometry using ammonia as reactant gas; ions at $m / z 789$ and 772 corresponding to $\mathrm{M}+$ $\mathrm{NH}_{4}^{+}$and $\mathrm{M}+\mathrm{H}^{+}$, respectively, as well as a metastable ion at $m / z 756$ corresponding to the 
<smiles>[Y]C(C)C(C)=CC=CC(C)C</smiles>

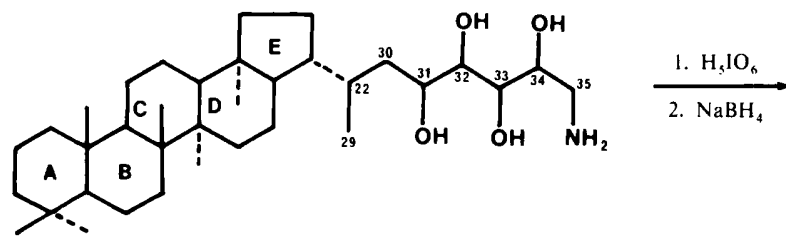

II<smiles>[Y]C(C)CCO</smiles>

IV

Fig. 1. The hopanoids of 'Methylosinus trichosporium' and their $\mathrm{H}_{5} \mathrm{IO}_{6} / \mathrm{NaBH}_{4}$ cleavage products. See text for details.

direct transition from $\mathrm{M}+\mathrm{NH}_{4}^{+}$to $\mathrm{M}+\mathrm{H}^{+}$were observed. The presence of the two ions at $m / z$ 771 and 550 suggests also that an oxygen atom is replaced by an NH group in the side chain. The position of the extra hydroxyl group at $\mathrm{C}-31$ is already indicated by the $\mathrm{C}_{31}$ skeleton of the $\mathrm{H}_{5} \mathrm{IO}_{6}$ cleavage product (IV) (Fig. 1). The ${ }^{1} \mathrm{H}-\mathrm{NMR}$ spectrum of peracetylated (II) showed a new signal at $5 \cdot 20$ p.p.m. corresponding to the proton at C-31. Furthermore, the presence of this new acetoxy group at C-31 slightly modified the chemical shifts of some of the methyl groups. The doublet corresponding to the methyl group at C-22 was shielded and appeared at 0.912 p.p.m. whereas it was at 0.901 p.p.m. in the spectrum of peracetylated (I) and the signal corresponding to the methyl groups located at $\mathrm{C}-8$ and $\mathrm{C}-14$ was split. These two methyl groups appeared as two singlets at 0.930 and 0.945 p.p.m. in the spectrum of the penta-acetate of (II), whereas they appeared as a unique singlet at 0.941 p.p.m. corresponding to six protons in the spectra of all other hopanoids lacking a functional group at C-31. The amino group of hopanoid (II) could be localized at C-35 for the same reasons as those described for the localization of the amino group of compound (I).

\section{DISCUSSION}

'Methylosinus trichosporium' is a good source of the two aminobacteriohopanepolyols (I) and (II) (Fig. 1). The aminotriol (I) was recently identified by us in the photosynthetic purple nonsulphur bacterium Rhodomicrobium vannielii (Neunlist et al., 1984, 1985). The isolation of this compound and of a higher homologue, the aminotetrol (II), from a methylotrophic bacterium belonging to an unrelated taxonomic group shows that these derivatives may be far more widespread in prokaryotes than previously expected. In several prokaryotes, the bacteriohopanepolyols are usually not present as free polyols, but are linked to polar moieties. Good examples are $\mathrm{N}$-acyl glycosides of bacteriohopanetetrol in Bacillus acidocaldarius (Langworthy \& Mayberry, 1976), $N$-aminoacyl derivatives of the aminotriol (I) in Rhodomicrobium vannielii (Neunlist et al., 1984, 1985) and bacteriohopanetetrol linked to various polyols via an ether linkage in Methylobacterium organophilum (J. M. Renoux \& M. Rohmer, unpublished results). Such polar derivatives could not be detected in 'Methylosinus trichosporium'. It seems that only the free aminopolyols (I) and (II) are present, since the amounts of hopanoids detected by two 
different procedures are essentially the same. The procedure involving the $\mathrm{H}_{5} \mathrm{IO}_{6}$ cleavage of the side-chain is able to detect all bacteriohopanepolyols as well as their known polar derivatives, whereas with the alternative procedure some very polar derivatives or those present in very small amounts could remain undetected.

Because of the similarities of the structures and the biosynthesis of sterols and hopanoids, we have postulated that the hopanoids might be the phylogenetic precursors of the sterols (Rohmer et al., 1979; Ourisson \& Rohmer, 1982). Experimental support has already been obtained using artificial biological membrane models such as phospholipid monolayers or unilamellar vesicles of phospholipid bilayers. In both cases hopanoids have been shown to induce a condensation of the normal acyl chains above the phase transition temperature of the phospholipids or to reinforce efficiently the bilayer, much like cholesterol (Poralla et al., 1980; Kannenberg et al., 1983; Benz et al., 1983; Bisseret et al., 1983). Furthermore, a physiological effect related to the presence of hopanoids could be observed in the thermoacidophilic bacterium Bacillus acidocaldarius: the hopanoid content of the cells increased dramatically with the growth temperature, probably corresponding to the need for more membrane reinforcers (Poralla et al., 1984). Since most of the methane-utilizing bacteria so far described in some conditions contain extensive intracytoplasmic membrane systems (Davies \& Whittenbury, 1970; Wolfe \& Higgins, 1979), it was reasonable to assume that they would be good hopanoid sources. In fact almost all methylotrophs so far analysed have contained hopanoids, the exceptions being 'Methylomonas clara' and 'Methylophilus methylotrophus' grown on an industrial scale by Hoechst and ICI, respectively (Rohmer et al., 1984). 'Methylosinus trichosporium' is able to utilize either methane or methanol as carbon and energy source (Best \& Higgins, 1981). Although one might expect a difference between the methane- and the methanol-grown cells, in fact the hopanoid content was qualitatively and quantitatively the same in the two culture conditions. This result is not too surprising since our 'Methylosinus trichosporium' cells were harvested in the late deceleration phase. In these conditions the methanol-grown cells, much like the methane-grown cells, contain a large intracytoplasmic membrane system (Best \& Higgins, 1981). Since the development of this membrane system is largely dependent on the growth conditions and the age of the culture, a careful control of these factors might reveal a correlation between the hopanoid content of the cells and the extension of the membrane system.

We acknowledge gratefully our debt to Professor $\mathrm{R}$. Whittenbury who helped us a few years ago in the growth of methylotrophs. Financial support was provided by grants of the Ministère de l'Industrie et de la Recherche and from the CNRS (LA 135, ATP Microbiologie 1983).

\section{REFERENCES}

Benz, R., Hallmann, D., Poralla, K. \& Eibl, H. (1983). Interaction of hopanoids with phosphatidylcholines containing oleic and $\omega$-cyclohexyldodecanoic acid in lipid bilayer membranes. Chemistry and Physics of Lipids 34, 7-24.

Best, D. J. \& Higgins, I. J. (1981). Methane-oxidizing activity and membrane morphology in a methanolgrown obligate methylotroph, Methylosinus trichosporium OB3b. Journal of General Microbiology 125, 73-84.

Bisseret, P., Wolff, G., Albrecht, A. M., Tanaka, T., Nakatani, Y. \& Ourisson, G. (1983). A direct study of the cohesion of lecithin bilayers. The effect of hopanoids and $\alpha, \omega$-dihydroxycarotenoids. Biochemical and Biophysical Research Communications 110, 320-324.

Budzikiewicz, H., Wilson, J. M. \& Djerassi, C. (1963). Mass spectrometry in structural and stereochemical methods. XXXII. Pentacyclic triterpenes. Journal of the American Chemical Society 85, 36883699 .
Davies, S. L. \& Whittenbury, R. (1970). Fine structure of methane and other hydrocarbon utilizing bacteria. Journal of General Microbiology 61, 227 232.

Dessort, D., Van Dorsselaer, A., Tian, S. I. \& VINCENDON, G. (1982). Electron impact mass spectrometry of non-volatile substances by fast heating. Tetrahedron Letters 1395-1398.

Förster, H. J., Biemann, K., Haigh, W. G., Tattrie, N. H. \& Colvin, J. R. (1973). The structure of novel $\mathrm{C}_{35}$ pentacyclic terpenes from Acetobacter xylinum. Biochemical Journal 135, 133-143.

Hou, C. T., Laskin, A. I. \& Patel, R. N. (1978). Growth and polysaccharide production by Methylocystis parvus OBBP on methanol. Applied and Environmental Microbiology 37, 800-804.

Kannenberg, E., Blume, A., McElhaney, R. N. \& PORAlla, K. (1983). Monolayer and calorimetric studies of phosphatidylcholines containing branched-chain fatty acids and of their interactions with cholesterol and with a bacterial hopanoid in 
model membranes. Biochimica et biophysica acta 733, $111-116$.

LANGWorthy, T. A. \& MAYBERRY, W. R. (1976). A 1,2,3,4-tetrahydroxypentane substituted pentacyclic triterpene from Bacillus acidocaldarius. Biochimica et biophysica acta 431, 570-577.

Neunlist, S., Rohmer, M., Holst, O., Borowiak, D. \& MAYER, H. (1984). Nouveaux hopanoïdes bactériens: aminopolyols et dérivés aminoacylés de Rhodomicrobium vannielii. Comptes rendus de l'Académie des sciences de Paris 298, 631-634.

Neunlist, S., Holst, O. \& Rohmer, M. (1985). Prokaryotic triterpenoids. The hopanoids of the purple non-sulphur bacterium Rhodomicrobium vannielii: an aminotriol and its aminoacyl derivatives, $N$-tryptophanyl and $N$-ornithinyl aminotriol. European Journal of Biochemistry (in the Press).

OURISSON, G. \& ROHMER, M. (1982). Prokaryotic polyterpenes: phylogenetic precursors of sterols. Current Topics in Membranes and Transport 17, 153-172.

Poralla, K., Kannenberg, E. \& Blume, A. (1980). A glycolipid containing hopane isolated from Bacillus acidocaldarius has a cholesterol like function in membranes. FEBS Letters 113, 107-110.

Poralla, K., Härtner, T. \& Kannenberg, E. (1984). Effect of temperature and $\mathrm{pH}$ on the hopanoid content of Bacillus acidocaldarius. FEMS Microbiology Letters 23, 253-256.

ROHMER, M. (1975). Triterpénoïdes de procaryotes. Thése d'Etat, Université Louis Pasteur, Strasbourg, France.
Rohmer, M. \& Ourisson, G. (1976a). Structure des bactériohopanetétrols d'Acetobacter xylinum. Tetrahedron Letters 3633-3636.

ROHMER, M. \& Ourisson, G. (1976b). Dérivés du bactériohopane: variations structurales et répartition. Tetrahedron Letters 3637-3640.

Rohmer, M., Bouvier, P. \& Ourisson, G. (1979). Molecular evolution of biomembranes: structural equivalents and phylogenetic precursors of sterols. Proceedings of the National Academy of Sciences of the United States of America 76, 847-851.

Rohmer, M., ANDing, C. \& Ourisson, G. (1980). Non-specific biosynthesis of hopane triterpenes by a cell-free system from Acetobacter pasteurianum. European Journal of Biochemistry 112, 541-547.

Rohmer, M., Bouvier-Nave, P. \& Ourisson, G. (1984). Distribution of hopanoid triterpenes in prokaryotes. Journal of General Microbiology 130, 1137-1150.

Skerman, V. B. D., McGowan, V. \& Sneath, P. H. A. (1980). Approved lists of bacterial names. International Journal of Systematic Bacteriology 30, 225-420.

Whittenbury, R., Phillips, K. C. \& Wilkinson, J. F. (1970). Enrichment and some properties of methane utilizing bacteria. Journal of General Microbiology 61, 205-218.

Wolfe, R. G. \& Higgins, I. J. (1979). Microbial biochemistry of methane - a study in contrasts. In International Review of Biochemistry, vol. 21, pp. 267-353. Edited by J. R. Quayle. Baltimore: University Park Press. 